Georgia State University

ScholarWorks @ Georgia State University

Middle and Secondary Education Faculty

Publications

Department of Middle and Secondary Education

2018

\title{
A Teacher Goes Gothic: Walter White, Heisenberg, and the Dark Revenge of Science
}

\author{
J. Patrick McGrail \\ Jacksonville State University \\ Ewa McGrail \\ Georgia State University \\ Alicja Rieger
}

Follow this and additional works at: https://scholarworks.gsu.edu/mse_facpub

Part of the Curriculum and Instruction Commons, and the Junior High, Intermediate, Middle School Education and Teaching Commons

\section{Recommended Citation}

McGrail, J. Patrick; McGrail, Ewa; and Rieger, Alicja, "A Teacher Goes Gothic: Walter White, Heisenberg, and the Dark Revenge of Science" (2018). Middle and Secondary Education Faculty Publications. 136. https://scholarworks.gsu.edu/mse_facpub/136

This Article is brought to you for free and open access by the Department of Middle and Secondary Education at ScholarWorks@ Georgia State University. It has been accepted for inclusion in Middle and Secondary Education Faculty Publications by an authorized administrator of ScholarWorks @ Georgia State University. For more information, please contact scholarworks@gsu.edu. 


\title{
A Teacher Goes Gothic: Walter White, Heisenberg and the Dark Revenge of Science J. Patrick McGrail, Ewa McGrail, Alicja Rieger
}

\begin{abstract}
Much has been written on the natures and personalities of teachers in educational research and publications (Carter, 2009; Beck, 2012; Bulman, 2015; Dalton, 2013; Gillard, 2012; Kelly \& Caughlan, 2011). However, mass media can have a powerful influence on how people see teachers. The television series Breaking Bad (Gilligan, 2007-2013) and its representation of teachers, has contributed a unique - if warped -perspective on the subject of teachers and teaching in America. In this article, we argue that three important Gothic and mythic fables from literature are harbingers of Walter White and his transformation - the Faust legend, as told by Christopher Marlowe (1604), the tale of Victor Frankenstein and his monster, by Mary Wollstonecraft Shelley (1818) and Robert Louis Stevenson's famous character, Mr. Edward Hyde (1886). We note that the comparisons, while apt, are imperfect, and we discuss the philosophical, social and literary implications of them.
\end{abstract}

Keywords: Gothic; Breaking Bad; teachers; teacher representation; drug trade; Walter White 


\section{A Teacher Goes Gothic: Walter White, Heisenberg and the Dark Revenge of Science}

\section{The High School Teacher in Film and Television}

High school teachers have been a favorite source for narrative in the popular cinema and on television for some time now (Kelly \& Caughlan, 2011; Reyes \& Rios, 2003; Schoffner, 2016). They have often been depicted as white, female and and as chivalrous bearers of the torch of civility and the liberality of the humanities to the underprivileged, who are frequently students of color (Beck, 2012; Author \& Author, 2016) and who are portrayed as either bored, actively hostile, or difficult to educate (Carter, 2009; Zoss et al., 2014). As such, many of these films embed the solution to contemporary problems of education in the personality of a single man or woman (Bulman, 2015).

In most of the well-known movies and programs of this kind [e.g., Freedom Writers (Shamberg \& LaGravenese, 2007), Dead Poets Society (Haft, Witt \&Weir, 1989), Dangerous Minds (Bruckheimer, Simpson, \& Smith, 1995) and Mr. Holland's Opus (Field et al., 1995)], the protagonists are English or humanities teachers. As such, their primary responsibility is to school their students in the beauty of Shakespeare or other literary luminaries from the distant past (Carter, 2009; Schoffner, 2016).

We found a few exceptions to these tidy humanities-extolling dramas; a few featured a central character who was a science or math teacher. Jaime Escalante, both the character in Stand and Deliver (Musca \& Menéndez, 1988), and the real world teacher, taught math with a message of perseverance and discipline. Another is Here Comes the Boom (Loeb, James, \& Coraci, 2012), a sentimental comedy featuring Kevin James as a biology teacher who 
moonlights as a wrestler to garner money to save the music and drama programs at his school. Prior to researching this article, however, we found none who were chemistry teachers.

It is for this distinction that we take note of the critically acclaimed television program (Wakeman, 2017), Breaking Bad (Gilligan, 2007-2013) and its chemistry teacher protagonist, Walter White. But, as we observe below, the fact that White teaches chemistry is both the source of the plot structure of this program, and the fount from which White's descent into evil and self-destruction springs.

Breaking Bad's (Gilligan, 2007-2013) Walter White, however, did not initially seek to be a high school teacher. His qualifications would ordinarily have led someone possessing them to become a research scientist. According to visual and scriptural details in Breaking Bad, White has a master's degree in chemistry from Caltech, worked at the prestigious Sandia Laboratories, and had conducted research on X-Ray crystallography that led to the 1985 Nobel Prize for two other people, which permitted them - but not White - to become famous and wealthy. (Breaking Bad wiki). Family financial pressures finally forced White to take a high school teaching job instead.

However Walter White's hesitant, timid manner conceals a deep frustration with what he has obviously come to regard as the failure of his life - his comparative lack of financial and professional success. When he learns he has Stage 3A inoperable lung cancer (Season 1, Episode 1), this puts into motion a series of decisions on his part that begin with deciding to manufacture methamphetamine. Such a decision confirms his possession of a dark nature, capable of criminality, and one whose latent evil leads to his own destruction, much like certain monstrous characters earlier seen in Gothic literature. 
Accordingly, our focus in this article is on the Walter White character's connection with several important narrative and mythic forerunning protagonists that exist in well-known literature and culture. Specifically, we argue that three important Gothic fables from literature are harbingers of Walter White and his transformation - the Faust legend, as encapsulated in the play by Christopher Marlowe (1604), the tale of Victor Frankenstein and his monster, in the novel by Mary Wollstonecraft Shelley (1818) and the Robert Louis Stevenson novella Dr. Jekyll and Mr. Hyde (1886). However, Breaking Bad (Gilligan, 2007-2013) does more than simply retell the new with the tools of the old; it uses for its grist the anxiety and economic uncertainty of the early 21st century to construct a protagonist who while working in the tatterdemalion profession of teaching commits shocking acts of evil.

\section{Walter White's Change by degrees into a Gothic Antihero}

Perhaps the most stunning aspect of Breaking Bad (Gilligan, 2007-2013) is how a seemingly ordinary high school chemistry teacher becomes a human monster over the course of the series. At first, White is intrigued by the quick and easy money of the methamphetamine trade, as a diagnosis on him of terminal cancer threatens his mortality and the well-being of his family, since he is the sole breadwinner. Also, Walter White's son Walt Jr. has cerebral palsy and White dotes on him.

One of the reasons the show puts forth for White's descent into the drug trade is that he fears his son will never be able to live and thrive on his own. Despite Walt Jr.'s relative normalcy, Walter's fear is presented as a realistic concern that might exist for many of the able bodied members of the program's audience. Therefore, Breaking Bad shows up "a serious 
disconnect between the dominant able bodied culture and disability culture" (Haller, 2010, p. 177 ) in terms of White's (and therefore, our own) perceptions of disability.

The series seems to suggest that such a fall is a potential "solution to the 'problem' of disability'” (Haller, 2010, p. 177). In other words, Walter White's choices implicate to audiences the message that seemingly the best option for someone in his situation (Haller, 2010) is to perform criminal acts under the pretext of survival and as support for his family. It is never suggested, on the other hand, that living a life as a disabled person "with the full gamut of human experiences from joyful to tragic" (Haller, 2010, p. 177) is at all possible.

Notably, Breaking Bad also illustrates how those with serious health problems in the US have even more serious financial difficulties when they seek to treat their infirmities (Falcon, 2016); Walter and his wife Skyler speculate that his cancer treatment, which will only prolong his life for a few years, will cost over ninety thousand dollars (“Cancer Man” episode, Season 1). Later, Walter calculates out loud how much money he will need to pay off the mortgage on his house, and send his son and unborn child to college after his death. The upshot? The total is nearly three quarters of a million dollars $(\$ 737,000$, to be exact). And this sum would be required from someone working as a high school teacher for a relative pittance:

WALTER: I am an extremely overqualified high school chemistry teacher. When I can work, I make $\$ 43,700$ per year. I have watched all of my colleagues and friends surpass me in every way imaginable. (Season 2, Episode 3) 
By the end of Season 5 of the program, Walter has vastly exceeded the sum needed to provide for his family after his passing; he has earned in the neighborhood of eighty million dollars (Season 5, Episode 10).

Unlike other flawed protagonists in popular series who are complex men with obvious deficiencies, like Andy Sipowicz from NYPD Blue (Bochco \& Milch, 1993), Raylan Givens from Justified (Yost, 2010), and Al Swearengen from Deadwood (Milch, 2004), Walter White wills the monster within him to be born. Those other protagonists are not the conscious authors of their personae, whereas Walter White creates a character for himself he calls "Heisenberg," a kind of nom de plume for the authorship of his signature blue methamphetamine:

DECLAN: Who the hell are you?

WALTER: You know. You all know exactly who I am. Say my name.

DECLAN: Do what? I don't... I don't have a damn clue who the hell you are.

WALTER: Yeah, you do. I'm the cook. I'm the man who killed Gus Fring.

DECLAN: Bullshit. Cartel got Fring.

WALTER: Are you sure?

[Declan looks at Mike and Mike shakes his head]

WALTER: That's right. Now, say my name.

DECLAN: [quietly] Heisenberg.

WALTER: You're goddamn right.

("Say My Name" Season 5, Episode 7)

However, one reason White may be seen particularly as a Gothic antihero, rather than merely a desperate science teacher who makes bad choices, is his breathtakingly rapid 
transformation. As Oli Mould (2012) has observed, when Walt "awakens," it is so that Walter White himself may be shunted aside to make way for a new persona:

JESSE: Tell me why you're doing this. Seriously.

WALTER: Why do you do it?

JESSE: Money, mainly.

WALTER: There you go.

JESSE: Nah. Come on, man! Some straight like you, giant stick up his ass ... all of a sudden at age, what, sixty - he's just gonna break bad?

WALTER: I'm fifty.

JESSE: It's weird, is all, okay? It doesn't compute. Listen, if you're gone crazy or something. I mean, if you've gone crazy, or depressed - I'm just saying - that's something I need to know about. Okay? That affects me.

WALTER: I am ... awake.

JESSE: What?

WALTER: Buy the RV. We start tomorrow.

(Breaking Bad, Pilot Episode)

In a few weeks, as recounted in the Pilot episode, Walter White the high school teacher has begun to create methamphetamine for sale, which would have been, earlier in Walter's life, unthinkable. Unlike Walter, other popular antiheroes generally do not start out as hapless and ineffectual, only to so quickly descend to White's steely perdition. Walter White slips into a criminal underworld and alters himself consciously, step by horrific step. 
At first, he sets a financial limit to his meth manufacture. Once certain needs of his family are met, he will get out of the business. Then, circumstances cause him to break that limit. He hides his illicit business from his wife, and then circumstances cause him to tell her what he does. Then, he goes into business with her to launder money. Initially, he seeks to keep the business between himself and his former student Jesse Pinkman, and then he acquires the partnership of several other hardened criminals. As time progresses, he moves from remaining at an exquisite remove from everything except making methamphetamine, to controlling more and more of the business end of the trade, and finally to proactively murdering nine men whom he believes will turn state's evidence against him.

Initially, he manages to conceal the details of his drug dealing from his wife Skyler until at last he is compelled to let her know just whom she has married:

WALTER: Who are you talking to right now? Who is it you think you see?...You clearly don't know who you're talking to, so let me clue you in. I am not in danger, Skyler. I am the danger. A guy opens his door and gets shot, and you think that of me? No! I am the one who knocks! (Season 4, Episode 6)

At one point in the third season, he even compels young Jesse to kill a rival drug chemist to save his own life. In the final season (Season $5 b$ ), he is no longer employed in the drug trade; he IS the drug trade in the American Southwest. The transmutation of his personality elements is complete; Walter White, high school chemistry teacher, has become "Heisenberg," the emperor of methamphetamine manufacture. 
What is perhaps most fascinating in the character of Walter White is the verve and sangfroid with which he comes to attack the problem of profiting at the drug trade. Apparently, a lifetime of being passed over for promotions and better prospects has made him blithely uncaring of risk. The ignominy of his lowly second job as a car wash attendant, and the benign contempt people have for his first job, high school science teacher, cause White not merely to feel obligated to perform illegal acts, but to come to exult in their successful commission. Throughout the five seasons of the show, he consoles himself and his associates with the consideration that no matter what circumstances have made him do, at least the proper application of chemistry, his beloved muse, will result in a purer, "better" illicit drug for people to consume; he is still a man of science. It is as if he were saying that while the scientist may have fallen, the science remains sacrosanct.

His physical transformation likewise forms a series of steps. The cancer drugs he takes cause his hair to fall out, so he shaves his head, but it is also for the ancillary "cool" factor. Likewise, first his van Dyke beard and second, his black hat appear (Season 1, Episode 7) and are further signals of the changes within the man himself, changes that signal the transmutation of Walter White into Heisenberg.

\section{Walter White and His Alter-Ego, Heisenberg}

Throughout the series, Walter White pays homage to the altar of science. He may have to produce methamphetamine to survive in the Darwinian 21st century, but his drugs will be as pure as science can make them - which is to say as pure as Walter White can make them. Walter is proving to himself and others that his supremacy as a chemist is unquestioned. But in 
doing this, he realizes that his persona, the retiring, contemplative and pliant Walter White, has to perish. Walter White the high school chemistry teacher synthesizes - much as he might a brand new chemical compound - from the elements of his persona a creature that could boldly do the things that Walter White the teacher wouldn't dare do. White calls this persona Heisenberg, after Werner Heisenberg, the 20th century German physicist and author of the Uncertainty Principle (Beyler, 2015). It is worth noting that Heisenberg the physicist died of cancer (Cassidy, 1993).

At first, Heisenberg is a roman a clef, an inside joke. Few people around him, including police, his family or anyone else, make the connection to the late physicist. But Heisenberg the meth maker is reified in the drug world as a legend, the originator of the region's most potent methamphetamine. The legend spreads from dealers to the police and finally to the Drug Enforcement Administration (DEA), for whom White's brother in law, Hank Schrader, works.

Walter's creature Heisenberg may be original to him, but it is also not himself, at least not in full. Heisenberg the meth cooker is more ruthless, more pragmatic, and more deadly than Walter the high school chemistry teacher. Heisenberg becomes a leader of men and is highly successful. But his continued existence has dire consequences for Walt the science teacher. The more often Heisenberg is present, the less Walt the high school teacher can be present. Gradually, but inexorably, Walter White/Heisenberg accomplishes a retreat from his family and his students by separating from his wife and letting his teaching job lapse. When the RV that Jesse Pinkman acquired for making meth is destroyed, Walter retreats further from social life by going into the employment of a much larger drug dealer in a state of the art underground lab. With every step, Heisenberg waxes, and Walter White wanes. With every 
success as a drug dealer, Walter the teacher must let the monster Heisenberg make more decisions.

Eventually, as recounted in Season 3, Episode 4, Walter White is placed on indefinite leave as a high school chemistry teacher. He devotes himself to his laboratory, where he can work not only on drug manufacture, but also on Heisenberg. This is necessary, because as he becomes more and more successful as a drug maker, as his signature blue methamphetamine becomes known far and wide, White is forced to commit more and more acts that would a short time ago been unthinkable. Dealing with Mexican drug lords, various henchmen and his uncertainly loyal partners causes Heisenberg to come to the fore more and more often. Finally, and especially in Seasons 4 and 5 of the program, Heisenberg is the persona in ascendancy, and Walter White, the hemmer and hawer, is in eclipse.

\section{Gothicism, Romanticism and Walter White}

Gothicism was a literary style that came to its apex in the early 19th century, with some of the work of the Romantic poets George Noel Gordon (Lord Byron), his friend Percy Bysshe Shelley and Shelley's wife, novelist Mary Wollstonecraft Shelley. The Romantics showed an obsessive interest in science, among other things (Smith, 2004), and Percy Shelley himself, besides his well-known literary exploits, had an interest in chemistry. Gothic literature may be said to exploit "sadistic psychological violence and other aberrant mental states, inverting the quotidian world of common sense for one in which broken taboos, voyeurism, and obsession were the norm" (Christiansen, 1988, p. 40).

As a Gothic narrative, Breaking Bad certainly invites viewers to explore Walter White's "sadistic psychological violence" (Christiansen, 1988, p.40). His obsession with money and 
power has become "the norm," to the point where he finds such anti-social desires and behaviors satisfying, indeed, almost erotic. Importantly, although Walter White himself recognizes the morbid state of his mind and acknowledges his perverse behaviors, he refuses to alter course. He sees his unnatural tendencies as daring and self-empowering because they seem to be an efficacious anodyne for his desperation. They are exciting and gratifying to him internally as well. These words written by Lord Byron, from his work The Corsair (Gordon/Byron, 1814), could easily have described the inner state of mind of Walter White:

He knew himself a villain-but he deem'd

The rest no better than the thing he seem'd;

And scorn'd the best as hypocrites who hid

Those deeds the bolder spirit plainly did.

He knew himself detested, but he knew

The hearts that loath'd him, crouch'd and dreaded too.

Lone, wild, and strange, he stood alike exempt

From all affection and from all contempt: (pp. I, XI)

Romantic poets, along with their interest in the macabre and decadent, were also fascinated by human mortality and the ability of the shifting sands of time to vitiate accomplishment and wipe away the memory of former supremacy. No doubt the memory of the well-known poem by Shelley was in show creator Vince Gilligan's mind when he entitled Episode 14 from Season 5 "Ozymandias":

I met a traveller from an antique land Who said: "Two vast and trunkless legs of stone 
Stand in the desert ... Near them, on the sand,

Half sunk, a shattered visage lies, whose frown,

And wrinkled lip, and sneer of cold command,

Tell that its sculptor well those passions read

Which yet survive, stamped on these lifeless things,

The hand that mocked them, and the heart that fed:

And on the pedestal these words appear:

"My name is Ozymandias, king of kings:

Look on my works, ye Mighty, and despair!"

Nothing beside remains. Round the decay

Of that colossal wreck, boundless and bare

The lone and level sands stretch far away.

Ozymandias, Percy Bysshe Shelley (1817)

Walter White intones the first few lines of the above poem in a voiceover for a promotional trailer for Season 5 of Breaking Bad (Gill, 2015). As the lines are spoken, we see the desert of New Mexico and are able to re-interpret the vanity and vacuity of Walter White's "empire" as being no more substantial nor long-lived than that of Ozymandias. However, for Walter White himself, the ephemerality of his success could not be less important; he believes his days are numbered and brief and he might as well "go out with a bang."

We believe, then, that the series is a neo-Gothic cautionary tale. It engenders horror in the viewer at someone's unforeseen descent into evil, even as it simultaneously dwells on the societal triggers that cause a "good" person to do shocking things, and at least at first, without 
repercussion. While Gothicism has been associated with a morbid interest in the power of evil (Smith, 2004), Breaking Bad (Gilligan, 2007-2013) takes an especial delight in the power of evil men to both crush and corrupt their opponents, even as it indicts the comparative impotence of American legal and societal checks on their evil (Wakeman, 2017).

\section{Walter White and Marlowe's Dr. Faustus (1604)}

FAUSTUS:

O, what a world of profit and delight,

Of power, of honour, and omnipotence,

Is promis'd to the studious artizan!

All things that move between the quiet poles

Shall be at my command: emperors and kings

Are but obeyed in their several provinces;

But his dominion that exceeds in this,

Stretcheth as far as doth the mind of man;

A sound magician is a demigod:

Here tire, my brains, to gain a deity.

The Tragical History of Dr. Faustus (Marlow, 1604, p.4),

The Tragical History of Dr. Faustus by Christopher Marlowe (1604) is an apt place to start in the search for Breaking Bad's (Gilligan, 2007-2013) mythic forebears. The medieval German legend of the sorcerer Faust was recounted in a 1587 text called the Faustbuch that 
was available to Marlowe (Davis, 2017). Dr. John Faustus, the protagonist, is a scientist who grows bored with traditional scientific study and longs for more challenging, forbidden arts. He makes a deal with the devil, and in return for twenty-four years of any earthly pleasures he desires, he deeds his soul to Lucifer in Act 5. Lucifer, unsurprisingly, comes to collect the debt. The play finishes with an admonishment for the brilliant to ponder well the source of great wealth:

\section{CHORUS:}

Faustus is gone: regard his hellish fall, Whose fiendful fortune may exhort the wise, Only to wonder at unlawful things, Whose deepness doth entice such forward wits To practise more than heavenly power permits. (Marlowe, 1604, p. 59)

The parallels with Walter White are significant. Vince Gilligan, his writers and directors, and actor Bryan Cranston all do an excellent job of showing the initial vacillation of White, as he is alternately enchanted by the money available and disgusted with the underworld figures he has to deal with in the manufacture of methamphetamine. Faustus, too, while overwhelmed with the money, women and fame promised him, is at first uncertain whether his practice of the necromantic arts will lead him to stray too widely from the path of salvation, and the visages of demons frighten him as well. However, there are important differences between these two men of science. 
Intellectually, White is a typical scientist who empirically studies every problem; he insists to bemused criminals that they should run their businesses with reason and pragmatism. He appears to have no religious convictions. For him, his interest in selling drugs is motivated by one thing - the desire to make money and acquire respect. As time and the series progress, he evinces a growing acceptance of himself as a man who of necessity is doing bad work very well; he displays a grim satisfaction at how much money drug production can provide. Faustus, too, seems to be impressed with the riches necromancy and the black arts can provide, and how even Helen of Troy herself can be provided to him, should he only attend to the business of signing over his soul to the devil. In the Tragical History (Marlowe, 1604 \& 1616), various subsidiary devils appear to Faustus, who evidently believes in and seeks to manipulate the spiritual underworld. Therefore, Faustus' flickering faith is certainly the main factor in his undoing, which is not true of Walter White.

However, the main distinction between the two works and the two characters is not so much the lack of religiosity in White; it is rather what motivates the two men in the first place to practice their arts in the service of evil. In the Tragical History (Marlowe, 1604 \& 1616), Dr. Faustus seeks fame, fortune and the attentions of beautiful women, and becomes frustrated with what he sees are the witless limitations on the black arts he is allowed to practice in order to acquire his heart's desires. Boredom, greed and lust, therefore, appear to be the main causes of his downfall. For Walter White, the maintenance of a certain standard of middle class life for his family is, at least at first, his primary motivator. He had counted on science to take him and his family to success and fortune, and when this was not to be, he was clearly willing to be flexible and to do whatever it took to acquire money and security. When cancer strikes him, he 
believes that his family will not survive without his financial contribution, however meager. Accidentally, he learns of the huge profits available to people in the illegal methamphetamine trade and he makes an astonishingly quick decision to participate (Season 1, Pilot).

The quickness of that decision probably spring from the other reason for his descent into evildoing - the fact that his friends, acquaintances and family fail to take him seriously as a man, as a scientist, and as a breadwinner. Thus, in contradistinction to Faustus, who would in other circumstances, given his personality and tastes, still have been tempted by the black arts to embrace the devil, it is doubtful that a financially secure Walter would ever have contemplated manufacturing a dangerous drug.

It is true that in both of these works, "Pride goeth before destruction, and an haughty spirit before a fall." (KJV, Proverbs, 16:18). Both White and Faustus are supremely confident in their vision and "sorcery," even if in White's case, it is just science practiced superlatively well. Both suffer greatly for their vaulting ambition, and both scoff at salvific opportunities to leave their evil ways. But White seems always to excuse his often horrific actions as a dogged, flinty, purposeful industriousness. Certainly though, years of being ignored, denigrated and dismissed by his students, family and friends figure into his transformation. Therefore, in the sense that the evil that both Faustus and White experience largely springs from defects in their character, they are similar and roughly comparable.

\section{Heisenberg, science and Walter White's Frankenstein}

The form of the monster on whom I had bestowed existence was forever 
before my eyes, and I raved incessantly concerning him.--Frankenstein: Or, the Modern

Prometheus, Chapter 5, by Mary Wollstonecraft Shelley's (1818)

Mary Wollstonecraft's Frankenstein(1818) is considered an important marker in the history both of Gothicism and early science fiction. Relying on the darkness of personality and character that had been indulged in by her husband, Percy Bysshe Shelley (Gill, 2015) and their mutual friend, Lord Byron, Mary Shelley recounts the tale of Victor Frankenstein through a series of letters which tell us of his successful efforts at reanimating dead matter and creating a living being from expired tissue.

So much has been done, exclaimed the soul of Frankenstein--more, far more, will I achieve; treading in the steps already marked, I will pioneer a new way, explore unknown powers, and unfold to the world the deepest mysteries of creation." (Wollstonecraft Shelley, 1818, Chapter 3)

However, his creature is not completely nor perfectly human and his visage and appearance are so loathsome to its creator that Victor Frankenstein soon cannot bear to look upon his creation.

The creature, for his part, is fully sentient and conscious both of his creator's deep disappointment in him and his own limitations. He is soon hunted as a miscreant, kills and otherwise creates mayhem, and ultimately never finds happiness. His creator, Victor Frankenstein, is left to contemplate what problems unfold when science is harnessed to unclean ends.

I had been the author of unalterable evils, and I lived in daily fear lest the monster whom I had created should perpetrate some new wickedness. I had an obscure feeling 
that all was not over and that he would still commit some signal crime, which by its enormity should almost efface the recollection of the past. (Wollstonecraft Shelley, 1818, Chapter 9)

The connection between Walter White and Victor Frankenstein is perhaps the most metaphorical of the three comparisons we draw. Unlike White, Victor Frankenstein actually creates a "man" who is physically and spatially separate from himself, as opposed to Heisenberg, who is a mere persona of Walter White. Yet, in the sense that each man has made a creature that they cannot fully control, the comparison may be considered apt. Walter White cannot act as Walter White when faced with situations that require - for survival's sake - that he act as Heisenberg; at the same time, the things that Heisenberg is forced to do - including ordering the murder of around a dozen people - are troubling to what little of Walter White there is left. Both White and Frankenstein realize that they have unleashed an uncontrollable juggernaut.

Ironically, the science Walter professes to worship has only a co-starring role in the drama of his success. It is his Frankenstein monster Heisenberg that motivates the drug scientist, emboldens him and enables him to do what must be done in hopes of vast monetary compensation. For the first three seasons of the series, however, Walter has a very uncertain relationship with Heisenberg. He truly despises the things he has to do - as Heisenberg - to remain viable in the meth trade. The ugliness of his participation in death and addiction are, at least at first, weighty in Walter White's soul. Gradually, as he goes toe to toe with murderous competitors and especially in defense of his young assistant, Jesse Pinkman, his heart hardens and he chalks up bad deeds only to what has to be done. In Shelley's Frankenstein (1818), the 
scientist Victor Frankenstein creates a feeling, speaking monster whose ugliness repulses everyone, including his "master":

Remember that I am thy creature; I ought to be thy Adam, but I am rather the fallen angel, whom thou drivest from joy for no misdeed. Everywhere I see bliss, from which I alone am irrevocably excluded. I was benevolent and good; misery made me a fiend. Make me happy, and I shall again be virtuous." (Wollstonecraft Shelley, 1818, Chapter 10)

For Walter White/Heisenberg, as long as Walter lacks the finances to live life as he chooses, Heisenberg cannot be happy, and therefore, he cannot, as the Frankenstein monster complains, be virtuous. As Walter wrestles with his Heisenberg identity, practicality forces him to confess his activities to his wife Skyler. He comes to a slow, painful life accommodation with her. As he confesses to her, he does his best to let her know that he had done everything for her and his son:

WALT: I've done a terrible thing. But I did it for a good reason. I did it for us. That [money] is college tuition for Walter Jr. and Holly, eighteen years down the road. And it's health insurance for you and the kids. For Junior's physical therapy. His SAT tutor. It's money for groceries and gas, for birthdays and graduation parties. Skyler, that money is for this roof over your head. For the mortgage that you are not going to be able to afford on a part time bookkeeper's salary when I'm gone. Please. Please. This money - I didn't steal it, it doesn't belong to anyone else. I earned it. The things I've done to earn it. They... the things I've had to do, I've got to live with them. Skyler, all 
that I've done, all the sacrifices I've made for this family will be for nothing if you don't accept what I've earned...(Breaking Bad, Season 3, “I.F.T.” Episode 3.)

\section{Heisenberg and Mr. Hyde}

Robert Louis Stevenson's The Strange Case of Dr. Jekyll and Mr. Hyde (1886) has probably had treatment by the greatest diversity of media of the three forebears we cite for Walter White/Heisenberg. Dozens of motion pictures, plays and retellings of the Jekyll and Hyde story have appeared (e.g., Frank Wildhorn's 1999's Jekyll \& Hyde musical; Rouben Mamoulian's 1931 Dr. Jekyll \& Mr. Hyde and Victor Fleming's 1941 remake), and even more than the other two famous tales, it has become a meme for the duality of human nature, for people who are described as two-faced, and for the hidden parts of our own human nature (Barton, 2010).

In Stevenson's (1886) novella, Dr. Henry Jekyll is a well-known and well-liked physician, prosperous and with impeccable manners. He is also, at fifty, precisely the same age as Walter White, when Breaking Bad (Gilligan, 2007-2013) begins. The conformity imposed upon Victorian men wears on Jekyll, and he devises a serum of some kind (its nature is not precisely revealed) that changes him into a violent, frightening psychopath that he names Edward Hyde. As time progresses, the evil that Hyde does, which includes murder, begins to frighten Jekyll, who still possesses the memories of what his alter-ego Hyde has done. He seeks to suppress the manifestation of Hyde with drugs, but the Hyde persona becomes ever stronger and Jekyll needs to consume more and more of his serum to maintain the countenance of Dr. Jekyll. The novella ends somewhat mysteriously; the Hyde character is come upon by the lawyer and the 
police and is dead, presumably poisoned by his Jekyll doppelgänger, who leaves a long note expressing his guilt and remorse.

The resemblances here between White/Heisenberg and Jekyll/Hyde are in some respects the strongest of the three comparisons we draw. As with Faustus and Victor Frankenstein, an abuse of science leads a good man to do evil deeds and adopt an evil character. And somewhat more en pointe with Breaking Bad, in The Strange Case Dr. Henry Jekyll is a fifty year old scientist who devises a persona, an alter ego to allow his true desires and pent up needs to be fulfilled.

We argue here that, in some sense, Walter White has created methamphetamine in order to create Heisenberg, because Heisenberg, like Hyde, is a fearsome but powerful person able to do all the things Walter White wishes he could do, but cannot do. And, like Edward Hyde, Heisenberg hides in plain sight, his Jekyll-like Walter White persona giving cover so ample that it takes more than a year for his brother in law, DEA agent Hank Schrader, to discover who he really is (Season 5, "Gliding Over All").

But then, the paths of the two storylines begin to diverge. Dr. Jekyll has precisely the opposite problem of Walter White; he may be a shy and buttoned-down scientist, but he is very wealthy, and he uses his wealth to conceal the true nature of his alter-ego, Mr. Hyde. Neither illness nor poverty, then, drive Jekyll to create Hyde, unlike the force that these two factors have on Walter White. A part of him simply wishes to live without the fetters of rules that bind other men. In the end, Jekyll seeks a life of excitement and licentiousness, not unlike what is desired by Dr. Faustus (Marlowe, 1604).

\section{Discussion and Conclusion}


In the comparisons that we have drawn we come to the problems both of complexity and oversimplification. Showrunner Vince Gilligan should be given credit for creating a story with distant forebears, but lacking a perfect twin in literary history. Neither Dr. Faustus, Dr. Jekyll nor Dr. Frankenstein create their monstrosities for reasons that are exactly like those of Walter White.

Gilligan's master stroke - having a high school chemistry teacher become a complex villain - has yielded a study of moral and ethical struggles against a backdrop of early $21^{\text {st }}$ century financial privation. Specifically, by telling himself - and Breaking Bad's audiences - that he makes methamphetamine and murders other people only in order to purchase the good life for his family, Walter White gives himself and us a pretext to view his criminal activity as "good" in some respects. From the point of view of moral rightness (Budziszewksi, 2014), the series is hence poised to explore, through the portrayal of the fallen character of White, that timetested universal question about the human condition, whether evil done for the sake of some good, such as one's family, can ever be justified, or whether such a rationalization is actually proof of an already corrupted nature.

However, one subset of White's family-based decision to manufacture drugs is significantly problematic. Although White's affection for his son with a disability is portrayed with depth and realism, the choice that he makes - to produce illicit drugs and commit horrific acts in their manufacture, and to do all this in no small measure because of concern for his son's wellbeing - seems hard to swallow given the circumstances of his son. Cerebral palsy is no death sentence; people with the condition thrive into old age, given proper accommodation and access. White's son is depicted as vital, energetic, clever and charming; he does not appear 
to need very much more than the average abled teen. Therefore, one of White's most salient reasons, that his descent into the drug demimonde is due to his son's condition, may strike some viewers as unenlightened.

There is yet another important question to which Breaking Bad attempts to bring attention, and that is our moment in American history, in which the internet and the "flattening" (Friedman, 2005) of our communicative and economic world have commodified education and shaken the pedestals upon which teachers formerly stood. This makes the struggles of a put-upon, frustrated man of science to meet his world's demands for ever more money and ever more prestige extremely relevant. As such, the series deals with the struggling middle class in the first decades of the 21st century. As Blevins and Wood (2015) have observed:

In the broad heroic tradition of Oedipus, Hamlet, Willy Loman and Michael Corleone, Walter White solidifies his place in that tradition, and while Gilligan's hero shares many of the generic traits of those others, White is unique: a hero that emerges from the 21st-century contexts of health care concerns, a fallen economy, indefinite gender roles, gun violence, and the confrontation with the ethnic other (primarily in the immigration issues arising from Mexican border violence). (p. 2)

Indeed, Gilligan and his writers and co-creators do not soft-sell the stratospheric prices that health care charges its patients, should one fall victim to cancer, nor the meager salaries of high school teachers. The sad, dun-colored Aztek automobile that Walter drives, and his struggle to make mortgage payments and deal with a future that cancer will significantly curtail drive the show home to ordinarily situated audiences, and no doubt, resonate with them 
(Couch, 2013). The vast expanse of White's environment, a desert in the perpetual clutch of drought, is a stand-in for the desert sands that finally overwhelmed Ozymandias.

Looking at all this from yet another perspective, that of the failed university researcher forced to teach in secondary schools, who, in a moral U-turn, becomes the American Southwest's premiere methamphetamine manufacturer and dealer, Breaking Bad (Gilligan, 2007-2013) contributes to a dimming of the flame of educational hopefulness in American culture. The perception that American audiences would accept at face value such a devastating indictment of the potential character of teachers - regarding such a characterization as "real" enough to be possible, is ultimately a reflection of what Gilligan and his co-creators must have perceived to be the declining quality of both teachers and secondary schools in the United States (Beck, 2012; Bulman, 2015; Krausz, 2003; Rochester, 2013). It is a perception that is only reinforced by the program's deceptive veneer of naturalism and its patina of Gothic perversions.

We believe that as seductive as they are artistically, biased representations of teachers need to be both interrogated and supplemented with counter-narratives that would depict complex, realistic, but honest, righteous and accomplished teachers in US schools, who in real life surely are more numerous than Walter Whites. We look forward to their creation on our screens both at home and at the multiplex. 


\section{References}

Author \& Author. (2016).

Barton, J. (2010). Movie adaptations of Dr. Jekyll and Mr. Hyde [Website]. Retrieved from https://film-production.knoji.com/movie-adaptations-of-dr-jekyll-and-mr-hyde/

Beck, B. (2012). The teacher from the black lagoon: Revenge of the bad teacher. Multicultural Perspectives, 14(2), 89-92. DOI: 10.1080/15210960.2012.673316

Beyler, R. (2015). Werner Heisenberg: German physicist and philosopher [biography]. Retrieved from https://www.britannica.com/biography/Werner-Heisenberg

Blevins, J., \& Wood, D. (2015). The methods of Breaking Bad: Essays on narrative, character and ethics. Jefferson, NC: McFarland \& Co.

Bochco, S., \& Milch, D. (Producers). (1993). NYPD blue [Television series]. United States: Fox Television Network.

Breaking Bad Wiki. http://breakingbad.wikia.com/wiki/Walter_White. Accessed February 20, 2017.

Bruckheimer, J., \& Simpson, D. (Producers), \& Smith, J. N. (Director). (1995). Dangerous minds [Motion picture]. United States: Buena Vista.

Budziszewksi, J. (2014). The line through the heart: Natural law as fact, theory and sign of contradiction. Wilmington, DE: ISI Books.

Bulman, R.C. (2015). Hollywood goes to high school: Cinema, schools, and American culture. New York: Worth Publishers.

Cassidy, D. C. (1993). Uncertainty: The life and science of Werner Heisenberg. New York: Henry Holt and Company. 
Carter, C. (2009). Priest, prostitute, or plumber? The construction of teachers as saints. English Education, 42(1), 61-90.

Christiansen, R. (1988). Romantic affinities: Portraits from an Age, 1780-1830. New York: G.P. Putnam and Sons.

Couch, A. (August 20, 2013). Breaking Bad: Philosophers Tackle Heisenberg in Book (Q\&A). The Hollywood Reporter. Accessed February 25, 2017, at http://www.hollywoodreporter.com/live-feed/breaking-bad-philosophers-tackleheisenberg-609801.

Davis, L. (2017). Marlow: The sources of Doctor Faustus. Retrieved from http://www.english.cam.ac.uk/cambridgeauthors/marlowe-sources-of-doctor-faustus/

Falcon, C. (2016, March). What's behind the health care crisis? Life Extension, 338-51.

Friedman, T. (2005). The world is flat: A brief history of the twenty-first century. New York: Farrar, Strauss and Giroux.

Gill, A. (2015). On the appropriation of Percy Bysshe Shelley's "Ozymandias" in AMC's Breaking Bad. Xavier Journal of Undergraduate Research, 3. Retrieved from https://xjur.wordpress.com/volume-3-2015/vol-3-print-edition/test-essay/

Gordon, G. N. (Lord Byron) (1814). The Corsair. Retrieved from Project Gutenberg on February 11, 2017. www.gutenberg.org

Haller, B. A. (2010). Representing disability in an ableist world: Essays on mass media. Louisville, KY: The Advocado Press.

Haft, S., \& Witt, P. J. (Producers). Weir, P. (Director). (1989). Dead poets society [Motion picture]. United States: Sony Pictures. 
Field, T., Nolin, M., Cort, R. W., Duncan, P. S., Kamen, M., Ship, T.,... (Producers) \& Herek, S., (Director). (1995). Mr. Holland's Opus [Motion Picture]. United States: Buena Vista Home Entertainment.

Fleming, V. (Director). (1941). Dr. Jekyll \& Mr. Hyde [Motion Picture]. USA: MGM.

Marlowe, C. (1604). The tragical history of Dr. Faustus. Retrieved February 11, 2017 from http://www.gutenberg.org/cache/epub/779/pg779.txt

Milch, D. (Producer). (2004). Deadwood [Television series]. United States: Paramount Television Network.

Mould, O. (2012). "Been Through the Desert on a Horse with No Name. In Koepsell, D.R., \& Arp, R.(Eds.) Breaking Bad and philosophy: Badder living through chemistry. Chicago, IL: Open Court. Kelly, S., \& Caughlan, S. (2011). The Hollywood teachers' perspective on authority. Pedagogies: An International Journal, 6(1), 46-65.

KJV, Proverbs, 16:18. King James Bible Online. Retrieved from https://www.kingjamesbibleonline.org/Proverbs-16-18/

Loeb, A., James, K. (Producers), \& Coraci, F. (Director). (2012). Here comes the boom [Motion Picture]. United States: Columbia Pictures.

Mamoulian, R. (Director). (1931). Dr. Jekyll \& Mr. Hyde [Motion Picture]. USA: Paramount Pictures.

Monaco, J. (2009). How to read a film: Movies, media and beyond (4th ed.). New York: Oxford University Press.

Musca, T. (Producer), \& Men'endez, R. (Director). (1988). Stand and deliver [Motion picture]. United States: Warner Bros. 
Reyes, X. A., \& Rios, D. I. (2003). Imaging teachers: In fact and in the mass media. Journal of Latinos and Education, 2, 3-11.

Shamberg, M. (Producer), \& LaGravenese, R. (Director). (2007). Freedom writers [Motion picture]. USA: Paramount Pictures.

Shelley, P.B. (1817). Ozymandias. Retrieved on January 4 from http://www.gutenberg.org/ebooks/4800

Smith, A. L. (2004). American Gothic fiction: An Introduction. New York: Continuum.

Stevenson, R. L. (1886). The strange case of Dr. Jekyll and Mr. Hyde. Retrieved January 4, from http://www.gutenberg.org/cache/epub/42/pg42.txt

Stoker, B. (1987). Dracula. New York, NY: Doubleday \& Company.

Zoss, M., Holbrook, T, McGrail, E., \& M. Albers, P. (2014). Knotty articulations: Preservice teacher reflections of teaching literacy in urban schools. English Education, 47(1), 33-68.

Wakeman, S. (2017). The 'one who knocks' and the 'one who waits': Gendered violence in Breaking Bad. Crime Media Culture, 1-16.

Wildhorn, F. (Composer). (1999). Jekyll \& Hyde [Musical]. Cherry Lane Music Company. Wollstonecraft Shelley, M. (1818). Frankenstein: Or, the Modern Prometheus. Retrieved January 4, 2017 from https://www.gutenberg.org/files/84/84-h/84-h.htm

Yost, G. (Producer). (2010). Justified [Television series]. United States: FX Productions. 